\title{
HUBUNGAN PATRON-KLIEN DALAM SISTEM MAWAH KEUBEU DI ACEH BARAT
}

\author{
Irma Juraida ${ }^{1}$, Rahmah Husna Yana ${ }^{2}$ Triyanto $^{3}$ Nurlian $^{4}$ \\ 1,2,3,4 Universitas Teuku Umar

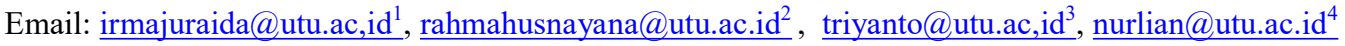

\begin{abstract}
This study aims to describe how the patron-client social interaction or relationship between the owner and the buffalo caretakers in Gampong Gunong Mata Ie, Aceh Barat Regency. This study uses the patron-client theory of James Scott using descriptive qualitative research methods with data collection techniques such as observation techniques, and in-depth interviews. The results of this study are a form of interaction or social exchange relationship between patron and client in mawah keubeu: a) material exchange relationship between livestock keepers and livestock owners b) non-material exchange relationships between buffalo breeders and buffalo livestock owners. The patron-client social exchange pattern between buffalo keepers and buffalo owners occurs because of economic inequality. The process of social exchange that occurs in buffalo keepers and buffalo owners is usually very strong and lasts a long time, this is due to the mutual benefit between clients and patrons.
\end{abstract}

Keywords: mawah keubeu, pertukaran sosial, patron-client,

\section{PENDAHULUAN}

Mawah merupakan salah satu kearifan lokal yang menggunakan sistem perjanjian bagi hasil dalam perekenomian masyarakat Aceh. Sistem bagi hasil dalam Bahasa Aceh disebut juga bagi hase'atau weuk hase' yaitu sistem yang berisi nilai-nilai dan normanorma tertentu tentang pembagian yang didapatkan oleh seseorang yang bekerja sebagai pengelola atau memelihara ternak milik pihak lain.

Sistem bagi hasil atau mawah ini merupakan suatu praktik perekonomian yang sangat diminati dalam masyarakat Aceh yang berazas pada sistem bagi hasil antara pemilik modal atau pihak yang mempunyai sumberdaya dengan pemelihara atau pengelola sumberdaya tersebut. Sistem mawah ini suatu mekanisme pihak yang memiliki modal menyerahkan hak pengelolaan modal tersebut kepada pihak lain dengan metode bagi hasil deengan ketentuan yang telah disepakati. Istilah mawah ini serupa dengan istilah gaduhan, yakni bagi hasil pada masyarakat Jawa dimana pemodal memberikan modalnya kepada pihak lain untuk dikembangkan (Octavira, Nurlina, \& 
Community: Volume 6, Nomor 2, Oktober 2020

p-ISSN: 2477-5746 e-ISSN: 2502-0544

Sulistyati, 2016). Jadi mawah ini merupakan praktik bagi hasil pada bidang pertanian (sawah, ladang, kebun) dan peternakan (lembu, kerbau, kambing, unggas) dimana hasil yang dibagikan sangat tergantung pada kesepakatan antara kedua belah pihak.

Perjanjian antara pemberi mawah (pemodal atau pemilik sumber daya) dengan penerima (pengelola) bedasarkan sistem bagi hasil. Praktik mawah memiliki banyak variasi yang juga dilakukan oleh masyarakat, sehingga mawah ini sangat lazim di Indonesia. Pada masyarakat nelayan praktik mawah bukan hanya dalam bentuk modal finansial saja, namun juga bisa oleh karena status sosial sehingga status yang tinggi memberikan dukungan dan perlindungan kepada nelayan yang berstatus lebih rendah (Sinaga, et al., 2015). Perlindungan dan dukungan ini banyak dibutuhkan oleh klien dalam kondisinya sebagai sebuah komponen yang kecil dimana akses dan kapasitas menjadi lebih terbatas.

Hal penting pada transaksi perjanjian mawah di Aceh Barat, adalah yang berkaitan tentang jumlah atau porsi bagi hasil antara pihak pihak yang berhubungan dalam sistem tersebut, lamanya perjanjian, cara pemeliharaan dan lainnya. Pembagian bagi hasil yang disepakati antara pemilik modal dengan pengelola modal sangat tergantung pada penjanjian awal yang sudah lazim dalam masyarakat tersebut.

Salah satu sistem mawah yang sangat terkenal dan diminati di Aceh Barat adalah mawah keubeu. Makna mawah keubeu ini adalah tentang pemelihaaran kerbau dengan sistem kearifan lokal. Tentu saja mawah keubeu ini tidak hanya terjadi di Aceh saja, namun juga di daerah lainnya dengan istilah yang berbeda-beda. Penelitian sebelumnya pernah dilakukan oleh Asriany, dimana sistem berternak kerbau yang diterapkan dalam bentuk kearifan lokal di daerah Randan Batu Kecamatan Makale Kabupaten Tana Toraja dibagi dalam dua bentuk, yang pertama, sistem kelompok peternak dengan menempatkan kandang kerbau pada lahan bersama (pekandangan kolektif), dan kedua adalah sistem individu peternak dengan menempatkan kandang kerbau pada lahan pribadi dengan pola pemeliharaan dikandangkan dan digembalakan, dan dilepas di padang pengembalaan (Asriany, 2017)

Kearifan mawah di Aceh terjalin melalui proses interaksi antara pemilik modal atau pemilik kerbau (patron) dengan penerima modal atau orang yang memelihara kerbau (klien). Interaksi yang terjadi dalam sistem mawah di Aceh Barat didasarkan pada proses interaksi dalam hubungan sosial dimana terdapat unsur hadiah, pengorbanan, dan keuntungan yang saling memengaruhi antara pemilik kerbau dengan pemelihara kerbau. Hubungan antara pemilik modal dengan pengelola terjadi pertukaran sosial yang saling menguntungkan.

Pada umumnya, proses interaksi atau hubungan sosial dialami oleh masyarakat berpusat pada pemberian hak pengelola dari pihak yang mempunyai modal atau sumberdaya kepada orang lain atau pihak lain. Hubungan pertukaran sosial ini diatur oleh norma-norma dan nilai nilai yang dipatuhi di tingkat struktur sosial masyarakat Aceh (Soekanto, 2003). Hubungan pertukaran sosial antara patron-kliennya ditandai oleh suatu perjanjian yang tidak tertulis antara pemilik modal atau ternak dengan dengan pihak pemelihara hewan ternak. Dalam proses interaksi atau hubungan sosial, 
pihak yang memiliki ternak mempunyai status sosial lebih tinggi dibandingkan pemelihara ternak. Meskipun pemelihara atau pengelola ternak menduduki posisi sebagai pengelola usaha, terbatasnya sumberdaya atau modal menyebabkan pihak perternak kurang mendapatkan wewenang didalam menentukan keputusan-keputusan sendiri.

Dalam perspektif sosiologis yang menempatkan pemelihara (kerbau) sebagai klein dan pemilik kerbau sebagai patron. Pemahaman sosiologis (Ritzer, 2007) masyarakat tersebut amat relevan, mengingat hal tersebut merupakan proses pertukaran sosial yang terjadi dalam masyarakat dan pertukaran sosial tersebut berlangsung di dalam jaringan relasi sosialnya. Kedudukan sosial patron klien dalam sistem hubungan atau proses interaksi yang terjadi dalam masyarakat Aceh, sehingga membentuk pola-pola pertukaran sosial dalam interaksi suatu struktur sosial masyarakat. Pertanyaannya adalah bagaimana hubungan patron-klien terbentuk? Dan bagaimana patron bersedia menyerahkan modalnya yang bernilai tinggi tersebut kepada klien? Sementara pada akhir-akhir ini banyak peternak hasil pemberdayaan dari desa sering melaporkan ternaknya yang mati dan hilang (Syafriati, 2019). Ini adalah perihal penting yang dapat dikembangkan sebagai salah satu model pembangunan desa untuk mengentaskan kemiskinan ke depan.

\section{TINJAUAN PUSTAKA}

Hubungan sosial yang terjalin dalam masyarakat dapat dilihat sebagai suatu proses pertukaran antara pihak-pihak yang ada dalam masyarakat tersebut. Pihak-pihak dalam masyarakat terjadi pertukaran sosial di sebabkan oleh tertarik pada pertukaran dengan mengharapkan balasan. Bentuk balasan yang dipertukarkan dapat bersifat instrinsik seperti pujian, rasa hormat, cinta, kasih sayang dan dapat pula yang bersifat ekstrinsik seperti uang dan tenaga kerja fisik (Blau, 1964). Meskipun demikian, tidak semua hubungan sosial atau interaksi merupakan proses pertukaran, menurut Blau suatu hubungan atau interaksi dalam masyarakat menjadi proses pertukaran jika masingmasing pihak yang berhubungan berorientasi pada tujuan-tujuan yang hanya dicapai melalui interaksi dengan maksud mendapatkan sarana dalam pencapaian

Pada dasarnya, untuk menjamin keberlansungan suatu proses interaksi atau hubungan patron-klien antara pihak-pihak yang terlibat dalam hubungan tersebut perrtukaran sosial harus seimbang atau setara. Hal ini menunjukan bahwa ganjaran atau hadiah yang dipertukarkan seharusnya kurang lebih harus seimbang nilainya dalam jangka panjang atau jangka pendek. Dengan demikian, pihak-pihak yang terlibat dalam proses pertukaran tersebut mempertahankan suatu keseimbangan yang memadai dalam proses pertukaran tersebut dengan mempertimbangkan keuntungan yang diberikan oleh orang lain harus dibalas (Johnson, 1988)

Pemberian ganjaran atau hadiah ada bersifat asimetris, dimana ada pihak-pihak yang status sosialnya lebih tinggi dan ada pihak yang status sosialnya lebih rendah. Penelitian yang telah dilakukan Ngadisah dalam konteks teori Blau, menyebutkan bahwa bila hubungan asimetris ini diwarnai pula dengan hubungan personal (bukan 
Community: Volume 6, Nomor 2, Oktober 2020

p-ISSN: 2477-5746 e-ISSN: 2502-0544

kontraktual) maka yang berlangsung disini adalah hubungan patron klien (Ngatijah, 1987).

Proses pertukaran sosial antara patron-klien terjadi dimana dua pihak orang atau lebih dimana pertukaran yang terjadi satu pihak mempunyai status yang lebih tinggi sehingga pihak tersebut bisa menggunakan statusnya untuk meyalurkan rasa aman secara ekonomi maupun sosial pada pihak lain atau klien yang status ekonominya lebih rendah, proses pertukaran dalam hubungan ini biasanya tidak seimbang. Status sosial yang tinggi disebabkan karena adanya kemampuan yang berbeda antara setiap orang dalam masyarakat.

Penjelasan di atas mendeskripsikan proses interaksi atau hubungan sosial yang terbentuk antara patron-klien. Dimana proses pertukaran sosial antara patron sebagai pemilik kerbau dan mempunyai tingkat ekonomi dan sosial yang lebih tinggi. Hal tersebut dapat memperoleh ganjaran atau hadiah maupun mampu menyalurkan modal atau sumber daya kepada pemelihara kerbau atau kliennya. Klien merupakan pemelihara kerbau yang memelihara kerbau sampai besar dan membutuhkan bantuan pemilik kerbau dalam hal modal dan pemasarannya.

Secara konseptual, proses pertukaran patron klien dapat terbentuk dalam masyarakat secara umum, baik masyarakat terbelakang maupun pada masyarakat yang sudah maju. Hubungan ini muncul karena ada perbedaan dalam sumberdaya yang dimiliki (kekayaan dan kekuasan). Untuk mempermudah pengertian serta untuk memperjelas bagaimana terjadinya hubungan patron klien, berikut ditampilkan kerangka bagaimana proses terbentuknya hubungan patron klien.

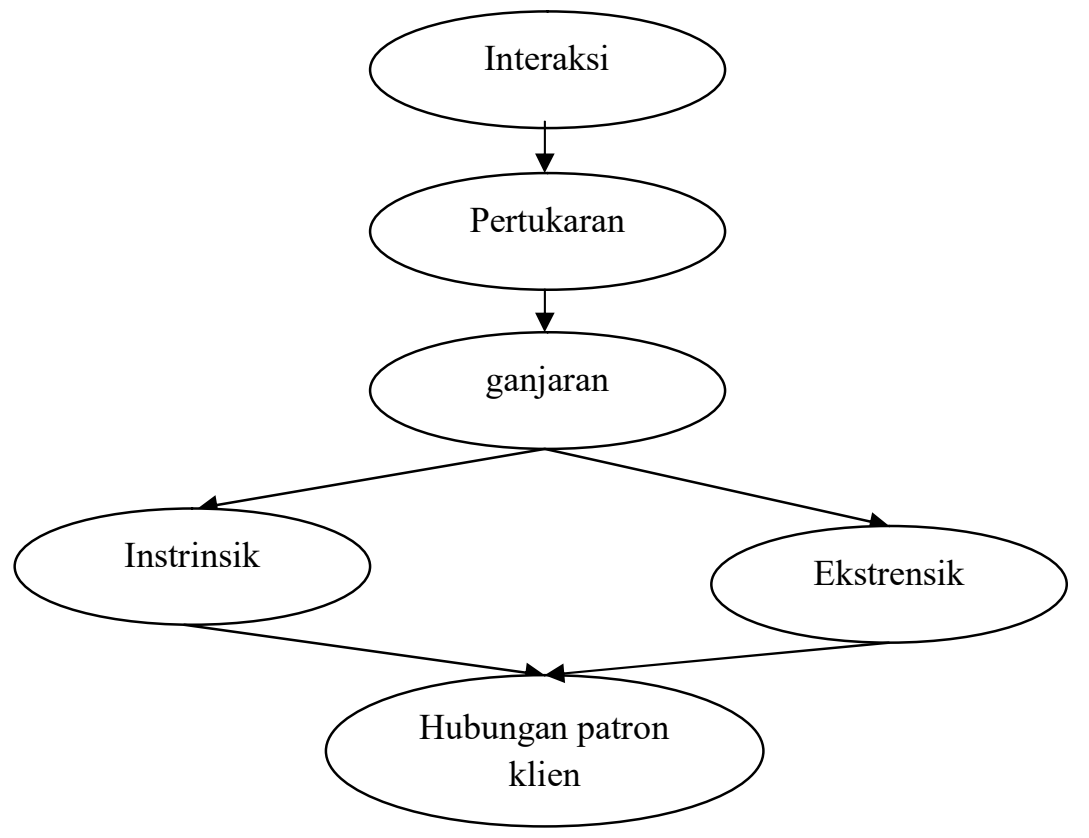

Gambar 2.1: Bagan Proses Terbentuknya Hubungan Patron Klien 
Berdasarkan kerangka berfikir di atas, dapat disimpulkan bahwa hal yang utama syarat terbentuknya hubungan patron klien yakni adanya hubungan sosial atau interaksi yang muncul dalam masyarakat. Dari hubungan sosial tersebut terbentuklah proses pertukaran antar kelompok sosial, pihak yang berminat kepada pihak lain dalam masyarakat, dimana pihak tersebut menganggap bahwa proses pertukaran tersebut akan mendapatkan hadiah atau keuntungan lebih besar dibandingkan pihak yang lain. Keberuntungan tersebut bisa diperoleh dalam bentuk intrinsik, seperti penghormatan, pujian dan kasih sayang, juga dalam bentuk ekstrensik yakni berupa uang, modal, dan jasa. Dengan demikian terciptalah hubungan patron klien.

\section{METODE PENELITIAN}

Penelitian ini dilaksanakan di Gampong Gunong Mata Ei Kecamatan Panton Reu Kabupaten Aceh Barat. Adapun pertimbangan dalam penentuan lokasi penelitian disebabkan oleh Gampong tersebut adalah salah satu wilayah pmelakukan proses pertukaran sosial melalui sistem mawah dan banyak masyarakat yang matapencahariannya sebagai perternak atau pemelihara kerbau. Metode yang digunakan dalam penelitian ini adalah penelitian yang bersifat kualitatif (Moleong, 2002). Data yang dibutuhkan dalam penelitian ini adalah data primer dan data sekunder. Data-data primer dan sekunder yang diperoleh di lapangan dikumpulkan untuk menjawab tujuan penelitian pertama dan dianalisa secara deskriptif, yaitu penganalisaan data dengan cara menggambarkan seluruh peristiwa objek penelitian dan mengguraikannya sesuai dengan data dan fakta yang ada di lapangan.

\section{HASIL DAN PEMBAHASAN}

\section{a. Proses Terbentuknya Hubungan Patron Klien}

Sebelum penulis menganalisis bagaimana pola hubungan yang terjadi antara peternak kerbau dengan pemilik kerbau, penulis mendiskripsikan bagaimana proses terjadinya hubungan antara petenak dengan pemilik kerbau dalam masyarakat tersebut. Penulis mulai mewawancarai informan kunci yaitu Saifuddin, dengan pertanyaan mengenai bagaimana cara memulai dan membentuk hubungan dengan pemilik ternak yang peliharanya. Saifuddin menjawab:

"Lon awai watee keunuk pelihara keubeu modal hana meupat cok, jadi lon jak lakee bantuan modal, untuk lon peulihara kerbau untuk meugang thon nyo". (ketika saya mau perlihara kerbau, saya kekurangan modal, sehingga saya meminta bantuan modal atau kerbau untuk saya pelihara agar dapat dipotong pada hari meugang tahun depan.

Disini tampak bahwa hubungan itu dimulai dari peternak sebagai klien yang mulai menjalin hubungan patron klien meminta hubungan dengan pemilik modal. Pada beberapa daerah dan pada umumnya terbentuknya hubungan patron klien ini akan diwali oleh peternak, hal ini dikarenakan pada umumnya memang klien yang lebih membutuhkan daripada patron. Hal ini selaras dengan disampaikan oleh Nurlatu bahwa klien membutuhkan perlindungan (Nurlatu, Jafar, \& Suharko, 2009). Pada hubungan 
Community: Volume 6, Nomor 2, Oktober 2020

p-ISSN: 2477-5746 e-ISSN: 2502-0544

patron klien mawah keubeu ini yang diharapkan klien adalah perlindungan modal dalam beternak kerbau.

Proses terjadinya hubungan patron-klien pada mawah keubeu ini sangat jelas bahwa seorang klien langsung meminta bantuan modal kepada patron baik berbentuk uang atau langsung berupa kerbau. Proses ini tentu bisa berbeda dengan terbentuknya patron-klien pada kasus atau pada masyarakat yang lain. Sebagai contoh proses terbentuknya patron-klien yang diawali dari mengajarkan bagaimana cara-cara menggemukkan kerbau (keubeu) sehingga pada akhirnya akan memberikan keuntungan yang besar saat meugang. Tanzil menunjukkan bagaimana proses terbentuknya patronklien pada masyarakat nelayan di Bau-Bau. Proses tersebut diawali karena seorang patron yang mengajarkan tentang apa-apa saja yang dilakukan saat melaut, cara-cara menggunakan alat tangkap dan seterusnya. Sebagai orang yang berbudi maka klien akan membalas kebaikan patron tersebut, maka kemudian terbentuknya hubungan patronklien tersebut (Tanzil, 2019).

Untuk melengkapi data dan melihat keseimbangan hubungan ini, penulis juga melakukan wawancara dengan pemilik ternak sebagai patron dalam hubungan ini, salah seorang pemilik yang juga patron adalah $\mathrm{Hj}$. Isa, pertanyaan ini lebih pada bagaimana bisa berhubungan dengan pertenak dalam hal modal, dan informan menjawab:

"Waktee awak gampong kemeung pelihara keubeu untuk hana peng, dijak bak lon dijak lakee modal, lon sebagai ureung na geujuok raseuki le Allah, wajeb lon bantu ureungnyo. Jadi hubungan nyan lagenya awai mula tabentuk". Artinya: (Hubungan ini bermula ketika pertenak mau memelihara kerbau datang kepada saya untuk meminta modal atau kerbau, sebagai umat Islam yang memiliki kelebihan rezeki saya berkewajiban membantu mereka, jadi hubungan kami mulai terjalin dari pinjam modal atau kerbau tersebut).

Berdasarkan wawancara yang penulis lakukan terlihat bagaimana pola hubungan patronase antara pemilik ternak dan pemelihara ternak terbentuk, disini posisi perternak sebagai klien memulai menciptakan hubungan dengan patron (toke pemilik ternak) dengan meminta modal atau kerbau untuk dipelihara dengan membagi hasil. Pemilik sebagai patron kemudian memberikan modal atau kerbau sehingga kemudian hubungan keduanya berubah dari pertemanan biasa menjadi hubungan patron-klien dalam masyarakat setempat.

Berdasarkan dari data di atas, diketahui bahwa sumber daya yang dimiliki perternak di Gampong Gunong Mata Ei, Kecamatan Panton Reu adalah dari hasil pemelihara ternak dengan sistem mawah. Sedangkan pemilik kerbau menguasai modal (uang) untuk membeli ternak. Proses tersebut merupakan salah satu faktor terbentuknya hubungan yang tidak setara, karena salah satu pihak jelas sebagai pemilik modal dan pihak sebelah dapat dibaratkan sebagai pekerja. Dengan hubungan yang demikian dikatakan dengan hubungan pertukaran antara patron klien. Kondisi inilah yang menyebabkan peternak menjalin hubungan dengan pemilik ternak dalam sistem mawah. 
Community: Volume 6, Nomor 2, Oktober 2020

p-ISSN: 2477-5746 e-ISSN: 2502-0544

\section{b. Hubungan Patron Klien Dalam Aktivitas Pertukaran}

Dalam aktivitas ini mereka yang terlibat di dalamnya adalah para peternak dan pemilik ternak. Hubungan pemelihara kerbau dengan pemilik menjadi hubungan dalam bentuk pemberi dan penerima. Pihak yang memiliki status sosial ekonomi yang lebih tinggi mempunyai kedudukan sebagai pemberi disebut pemiliki modal (kerbau) dan penerima adalah peternak atau yang memelihara kerbau.

Dalam sistem mawah peran yang dibawakan oleh pemilik kerbau terhadap pemelihara adalah bahwa pemilik merupakan pemasok atau penyedia kerbau untuk dipelihara dan juga memenuhi kebutuhan pokok perternak di Gampong Gunong Mata Ei, Kecamatan Panton Reu. Peternak dapat memenuhi kebutuhan hidup dari hasil usahanya sebagai pemelihara, dengan demikian peternak mendapatkan kebutuhan yang berasal dari pemilik ternak. Oleh sebab dalam memperoleh atau memenuhi kebutuhan hidup, peternak sering tidak punya uang untuk memenuhi kebutuhan sehari-hari atau kebutuhan lain yang mendesak seperti membayar uang sekolah anak, dan membayar biaya berobat jika salah satu anggota keluarganya sakit. Karena sumber pendapatan mereka berasal dari beternak, dan keluarga jarang meminjami uang, sehingga perternak tergantung kepada pemilik ternak.

Hal tersebut terlihat ketika peneliti mewawancarai Somad salah satu pemilik ternak yang merupakan informan dari unsur patron, kepada Somad ditanyakan mengenai alasan meminjamkan uang pada pemilik ternak, informan ini mengatakan karena kebutuhan si klien.

"Peternak berhubungan dengan pemilik ternak disini adalah karena faktor ekonomi, banyak diantara peternak di Gampong Gunong Mata Ie, ketika menunggu masa ternak kerbau siap jual yaitu pada masa meugang, mereka tidak mempunyai belanja untuk memenuhi kebutuhan sehari-hari, apalagi kalau ada salah satu anggota dari keluarganya yang sakit, yah.. nantinya sebagai balasan mereka menjual bagian bagi hasil dalam mawah-nya (pada pemilik ternak)".

Dalam pola hubungan patron-klien, pihak-pihak yang terlibat tidak hanya pada proses pertukaran barang atau jasa, tetapi lebih pada perkara menarik keuntungan dari pertukaran itu. Dalam hubungan sosial yang terjalin lebih bersifat tatap muka bersifat luwes, dan saling percaya diantara kedua pihak.

Berdasarkan dari hasil wawancara dengan Somad menyebutkan bahwa hubungan peternak dengan pemilik ternak pada umumnya bersifat informal, hubungannya biasanya didasari atas kepercayaan. Hubungan yang disebabkan oleh karena kepercayaan tersebut maka akan lebih kearah pertemanan, keluarga maupun tetangga. Hal inilah yang membedakan hubungan patron klien dengan hubungan sosial lainnya. "Hubungan peternak dengan pemilik ternak di gampong didasari oleh hubungan kekeluargaan, teman sekampung atau tetangga, sehingga dengan hubungan demikian tumbuh rasa saling percaya diantara kedua belah pihak", kata Somad.

Dengan demikian, berdasarkan hasil wawancara dengan beberapa informan di atas dapat disimpulkan bahwa dalam pola hubungan patron klien antara peternak dengan pemilik ternak selalu mempunyai hal-hal yang pertukaran baik barang atau jasa. 
Community: Volume 6, Nomor 2, Oktober 2020

p-ISSN: 2477-5746 e-ISSN: 2502-0544

Proses pertukaran sosial yang terjadi selalu menguntungkan kedua belah pihak yang terlibat dalam pola hubungan patron klien, dan pertukaran tersebut bisa dilihat sebagai bentuk hubungan atau pertukaran yang bersifat personal, intim, timbal balik, tatap muka serta luwes antar pelaku yang memperlihatkan ketidakseimbangan sumber-sumber. Pada kajian-kajian lainnya untuk menggambarkan hal ini lazim disebut sebagai hubungan kekeluargaan. Pada dasarnya, ikatan ini lahir sering lebih berdasarkan pada hubungan atau ikatan ketetanggaan atau kekeluargaan (Tanzil, 2019).

Dengan demikian semua indikator di atas saling berkaitan antara satu dengan yang lainnya dan tidak dapat berdiri sendiri. Oleh karena itu, proses pertukaran sosial pada patron klien itu tidak bisa terbentuk jika salah satu unsur itu tidak ditemukan dalam proses pertukaran tersebut.

\section{c. Hubungan Patron Klien Saling Menguntungkan.}

Pertukaran sumber daya yang terjadi antara peternak dengan pemilik ternak di Gampong Gunong Mata Ie ialah hubungan pertukaran sosial yang menguntungkan kedua belah pihak. Ganjaran atau hadiah yang menguntungkan tersebut sebagai unsur pembentukan pola hubungan patron klien tidak akan berlangsung.

Pernyataan di atas, memunculkan beberapa pertanyaan yang sering dipertanyaankan, bagaimanakah proses pertukaran tersebut membentuk patron-klien? Dengan demikin bisa dijelaskan patron-klien terbentuk karena faktor saling menguntungkan dan mendapat ganjaran dari hubungan atau pertukaran tersebut. Sehingga ada pihak yang mendapatkan keuntungan lebih besar dari pihak lain. Misalnya, pemilik ternak dari keuntungan menjalin hubungan dengan laba yang besar saat hasil ternak di jual dari pada pemelihara ternak.

Adanya unsur saling menguntungkan dalam pola hubungan patron klien telah dibuktikan juga oleh beberapa ahli Indonesia yang banyak membicarakan masalah ini (Sutrisno, 1988). Dari kenyataan empiris ini, pada hubungan patron klien telah dikelompokkan dalam teori pertukaran, dimana asumsi dasar adalah, transaksi pertukaran akan terjadi apabila kedua belah pihak dapat memperoleh keuntungan dari pertukaran itu.

Saling menguntungkan antara patron dan klien dapat dilihat dalam proses pemeliharaan ternak keubeu ini. Seorang patron tidak perlu lagi memikirkan bagaimana merawat keubeu agar pada saat meugang bisa memberikan keuntungan. Tugas pemeliharaan akan diambil alih oleh klien, dimana klien tidak perlu memikirkan untuk menyediakan atau mencari modal untuk membeli keubeu, karena sudah ditangani oleh patron. Untuk itu, klien bertugas memelihara agar gemuk dan memberikan keuntungan yang besar saat meugang. Klien perlu memberikan pakan, menjaga agar tidak hilang, dan merawat kandangnya. Bahkan peternak kerbau di Kendal juga memperhatikan kesehatan kerbaunya, sehingga penting untuk memanggil mantri ternak (Fitriyani, 2016).

Proses pertukaran sosial patron klien yang terjadi antara peternak dengan pemilik ternak di Gampong Gunong Mata Ie mendapatkan hasil bahwa dalam proses 
pertukaran mendapat keuntungan yang diperoleh dari kedua belah pihak baik bentuk keuntungan, materi maupun non materi. Keuntungan materi pemilik ternak diperoleh dari berbagai sumber, terutama dari pembelian hasil pembagian ternak dalam sistem mawah. Keuntungan materi yang diterima peternak adalah pinjaman tanpa bunga dari pemilik ternak jika memerlukannya. Pinjaman ini hanya diberikan pemilik ternak kepada peternak yang menjadi kliennya

Hasil wawancara dan pengamatan di samping keuntungan materi, Pada ternyatanya dalam proses pertukaran tersebut kedua pihak mendapatkan keuntungan non materi. Pemilik ternak juga mempunyai keuntungan berupa kedudukan sosial lebih tinggi serta dihormati oleh kliennya sendiri. Sedangkan keuntungan non materi yang diperoleh peternak adalah pemelihara ternak merasa nyaman jika sewaktu-waktu memerlukan uang bisa langsung meminjamkan pada tengkulak patronnya dengan mudah. Untuk Memperjelas keuntungan materi dan non materi yang didapat oleh kedua belah pihak dapat dilihat pada gambar di bawah ini:

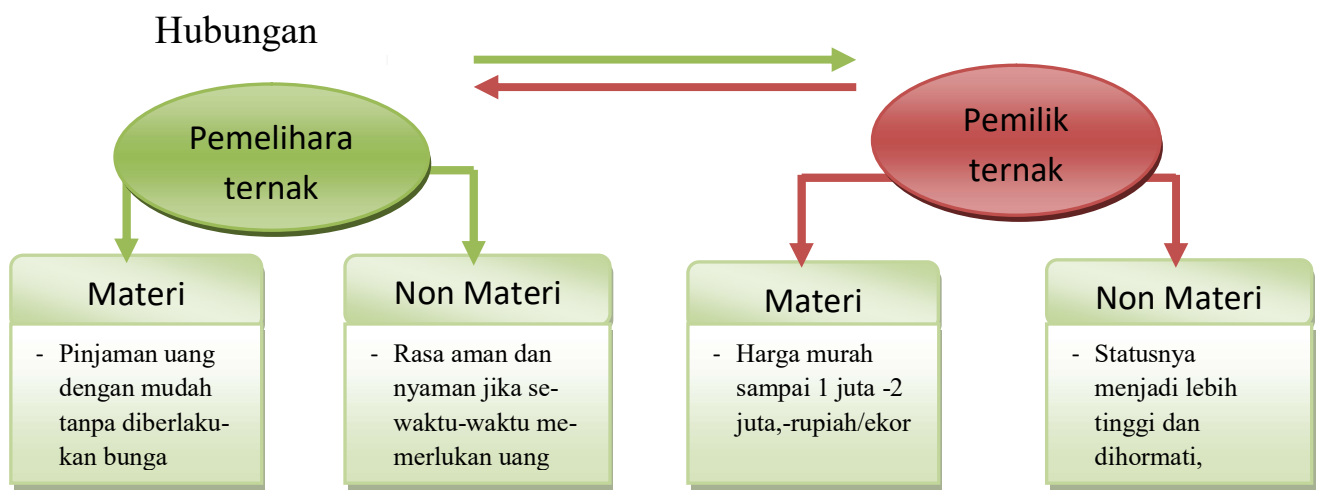

Gambar 4.1. Pola Pertukaran Saling Menguntungkan

Berdasarkan dari gambar di atas, dapat disimpulkan bahwa keuntungan yang diperoleh dari kedua belah pihak terjadi dapat memperoleh keuntungan, baik keuntungan materi maupun keuntungan non materi. Hubungan pertukaran sosial peternak dengan pemilik ternak ialah suatu proses pertukaran sosial yang didalamnya ada tujuan untuk memenuhi kebutuhan ekonomi pihak-pihak yang terlibat dalam pola hubungan tersebut. Dalam hubungan patron-klien selain tujuan ekonomis juga melibatkan tujuan non-ekonomis, seperti hubungan kekeluargaan maupun pertemanan.

Aktualisasi atau proses yang terbentuk dari hubungan non-ekonomis berupa hubungan saling tolong-menolong dalam berbagai kesulitan yang dihadapi oleh pihakpihak yang terlibat dalam pertukaran sosial tersebut. Proses pertukaran patron dan klien ini lebih bersifat elastis, sehingga tidak mudah diputuskan (Wolf, 1985) atau dengan kata lain hubungan tersebut bersifat "koalisasi".

Peternak maupun pemilik ternak dalam memperluas hubungan ekonomis menjadi non-ekonomis adalah saling memperlakukan sebagai keluarga sendiri, sehingga antara pemelihara kerbau atau ternak dengan pemilik modal atau kerbau terjalin hubungan pribadi, bersifat khusus dan mengandung kemesraan. Dan ini dapat terjadi 
Community: Volume 6, Nomor 2, Oktober 2020

p-ISSN: 2477-5746 e-ISSN: 2502-0544

karena kedua pihak mendiami suatu lokasi tempat tinggal yang sama, setiap hari bertatap muka dan saling bertegur sapa.

\section{d. Hubungan patron-klien saling Mempercayai}

Pada umummnya terbentuk pola interaksi pertukaran sosial patron klien tidak semua bersifat formal, namun lebih banyak yang bersifat informal. Oleh karena itu, peternak dan pemilik ternak terlibat dalam hubungan patron klien membina hubungan saling percaya dalam rangka kerjasama jangka panjang.

Faktor paling utama dalam membina saling percaya pada hubungan kerja sama itu adalah kejujuran dan kepatuhan pada kewajiban masing-masing pihak. Bagi tengkulak, kepercayaan yang diberikan petani sangat penting artinya, karena sebagai orang yang dihormati dan terpandang di kalangan masyarakat petani, tinggi rendahnya penghargaan dan penghormatan terletak pada kadar kepercayaan para petani terhadapnya.

Kecurangan sangat kecil terjadi di antara kedua belah pihak, hal ini terjadi karena pemilik modal atau ternak dengan mudah mengontrol apa yang dilakukan oleh pemelihara ternak. Artinya, tidak ada kesempatan bagi peternak untuk berbuat curang, jika mereka menjual hasil produksinya kepada orang lain, maka hubungan kerja tetap dilakukan tetapi sudah mulai muncul ketidaksenangan dengan kliennya.

Tanpa adanya kepercayaan ini, peternak bukan saja mendapat ancaman pemutusan hubungan kerja yang telah dilakukan, tetapi pemilik ternak juga sukar untuk memberi pinjaman klien yang tidak dipercayai. Uraian di atas menunjukkan adanya usaha ke dua belah pihak, untuk selalu menghindari konflik yang mungkin dapat terjadi. Kedua belah pihak berusaha untuk saling memaafkan atau saling menasehati dan mendiamkan jika kesalahan-kesalahan kecil yang diperbuat. Selama tindakan itu diambil, selama itu pula kerjasama antar keduanya dapat berlangsung.

Oleh karena itu bisa disimpulkan, tingkah laku paradoks, dengan tujuan ekonomis di satu pihak, dengan tenggang rasa di pihak lain, sehingga rasionalitas ekonomi yang semula mendasari pola hubungan keduanya terpaksa dikebelakangkan. Sifat tradisional pedesaan yang lebih mengutamakan perasaan dari pada rasio belum bisa ditinggalkan, sementara pengelolaan suatu aktivitas ekonomi yang menyangkut hajat hidup menurut tingkat rasionalitas yang tinggi, dan sifat ini mungkin dianggap sebahagian ahli sebagai suatu hambatan menuju tata cara mengelola perekonomian moderen.

\section{PENUTUP}

Berdasarkan data-data hasil penelitian yang dilakukan terlihat bagaimana pola hubungan patronase antara pemilik ternak dan pemelihara ternak terbentuk, disini posisi perternak sebagai klien memulai menciptakan hubungan dengan patron (toke pemilik ternak) dengan meminta modal berupa keubeu (kerbau) untuk dipelihara dengan menjanjikan bagi hasil. Pemilik modal sebagai patron kemudian memberikan modal 
sehingga hubungan keduanya berubah dari pertemanan biasa menjadi hubungan patronklien dalam masyarakat setempat.

Sementara itu bagaimana modal yang begitu besar dapat diberikan kepada klien, hal ini lebih dikarenakan adalah bahwa pada dasarnya antara patron dan klien sudah memiliki modal paling mendasar yaitu kepercayaan. Artinya seorang klien memang bisa memberikan jaminan bahwa klien bisa dipercaya, sementara patron benar-benar bisa mempercayai klien untuk mengelola modalnya. Kepercayaannya tentu didasari atas kepiawaian klien dalam memelihara keubeu juga adanya keuntungan yang bakal diraihnya saat meugang. Dengan demikian meskipun banyak kasus pemberdayaan yang melaporkan bahwa peternak mengalami bangkrut karena ternaknya mati, hal ini tidak mengurangi kepercayaan patron. Ada hal mendasar dalam hal ini yaitu hubungan emosional yang dibangun oleh patron dan klien, sementara pada pemberdayaan biasanya kurang memanfaatkan hubungan emosional.

\section{DAFTAR PUSTAKA}

Asriany, A., 2017. Kearifan Lokal Dalam Pemeliharaan Kerbau Lokal di Desa Randan Batu Kabupaten Tana Toraja, Makassar: Universitas Hasanuddin .

Blau, P. M., 1964. Exchange and Power in Social Life. New York: John Wiley \& Sons, Inc.

Fitriyani, E., 2016. Tinjauan Ekonomi Islam Terhadap Sistem "Gadhoh" Dalam Usaha Peternakan Kerbau di Desa Campurejo Kecamatan Boja Kabupaten Kendal Jawa Tengah, Semarang: Jurusan Ekonomi islam Fakultas Ekonomi dan Bisnis Islam Universitas Islam Negeri Walisongo.

Johnson, D. P., 1988. Teori Sosiologi Klasik dan Modern. Jakarta: PT. Gramedia Pustaka Utama..

Moleong, L. J., 2002. Metodologi Penelitian Kualitatif. Bandung: PT Remaja Rosdakarya..

Ngatijah, 1987. Hubungan Patron-Klien Dalam Sektor Informal (Studi Kasus di Pasar Kecamatan Pasar Minggu). Tesis S2 Sosiologi Program Pascasarjana Universitas Indonesia, pp. 44-56.

Nurlatu, Jafar \& Suharko, 2009. Relasi Patron Klien Antara Saudagar Dengan Pemilik Lahan Kayu Putih Desa Waeperang dan Desa Jikumerasa Kecamatan Namlea Kabupaten Maluku, Yogyakarta: Universitas Gadjah Mada.

Octavira, R. A., Nurlina, L. \& Sulistyati, M., 2016. Respon Peternak Terhadap Pola Bagi Hasil Anakan Usaha Ternak Kambing Perah (Studi Kasus Pada Kelompok Mandiri, Desa Girikerto, Kecamatan Turi, Kabupaten Sleman, Yogyakarta). Students e-Journals, pp. 1-14.

Ritzer, G. d. D. J. G., 2007. Teori Sosiologi Modern. Jakarta: Kencana.. 
Community: Volume 6, Nomor 2, Oktober 2020

p-ISSN: 2477-5746 e-ISSN: 2502-0544

Sinaga, H., Widiono, S. \& I., 2015. Pola Hubungan Patron-Klien Pada Komunitas Nelayan di Kelurahan Malabro Kecamatan Teluk Segara Kota Bengkulu. AGRISEP, 15(2), pp. 167-176.

Soekanto, S., 2003. Sosiologi Suatu Pengantar. Jakarta: PT RajaGrafindo Persada.

Sutrisno, M. d. L., 1988. Studi Pengembangan Desa Pantai di Propinsi Riau. Yogyakarta: Pusat Penelitian Pembangunan Pedesaan dan Kawasan Universitas Gadjah Mada.

Syafriati, 2019. Evaluasi Pelaksanaan Program Budidaya Ikan Lele Kelompok Perempuan Di Gampong Rukoen Damee Kecamatan Babahrot Kabupaten Aceh Barat Daya, Meulaboh: Prodi Sosiologi Fakultas Ilmu Sosial dan Ilmu Politik Universitas Teuku Umar.

Tanzil, 2019. Peranan Jariga Sosial Dalam Penanganan Kemiskinan Nelayan di Bau Bau. SOSIO KONSEPSIA, 8(2), pp. 61-71.

Wolf, e. R., 1985. . Petani; Suatu Tinjauan Antropologis. Jakarta: Rajawali Press.. 